\title{
PROBLEM REWINDYKACJI KOŚCIELNEJ NIERUCHOMOŚCI POLSKIEGO KOŚCIOŁA EWANGELICZNYCH CHRZEŚCIJAN BAPTYSTÓW WE WROCŁAWIU
}

\section{Streszczenie}

Zasadniczym celem niniejszego artykułu jest ukazanie przebiegu postępowania rewindykacyjnego nieruchomości kościelnej należącej do parafii Polskiego Kościoła Ewangelicznych Chrześcijan Baptystów we Wrocławiu, wraz z analizą wydanych $w$ toku postępowania decyzji administracyjnych. Szczególna uwaga została zwrócona na zagadnienia prawne związane z zastosowaniem art. 2 ust. 4 dekretu $\mathrm{z}$ dnia 8 marca 1946 r. o majątkach opuszczonych i poniemieckich oraz konsekwencjami uchwały Sądu Najwyższego z 19 grudnia 1959 roku co do skutków prawnych interpretacji art. 2 ust. 4 tego dekretu. W tej sprawie prawomocna decyzja o odmowie przyznania Kościołowi prawa własności została wydana dopiero po 13 latach od złożenia wniosku rewindykacyjnego. W toku całego postępowania doszło do przewlekłości, co potwierdził wyrok Europejskiego Trybunału Praw Człowieka w sprawie ze skargi nr 32045/10. Drugi Zbór we Wrocławiu (następca prawny wspomnianej wyżej parafii) nie odzyskał prawa własności nieruchomości utraconej po II wojnie światowej na podstawie przepisów ustawy regulującej sytuację prawną Kościoła Chrześcijan Baptystów w Rzeczypospolitej Polskiej. Okoliczności faktyczne przedstawione w niniejszym artykule na kanwie wieloletniego sporu rewindykacyjnego pozwalają na wyprowadzenie wniosków o konieczności uregulowania prawa własności tej nieruchomości w innym trybie niż administracyjny.

Słowa kluczowe: rewindykacja; nieruchomość kościelna; Polski Kościół Ewangelicznych Chrześcijan Baptystów; majątek poniemiecki; baptyści

* Dr, Katedra Prawa Wyznaniowego, Wydział Prawa, Prawa Kanonicznego i Administracji, Katolicki Uniwersytet Lubelski Jana Pawła II, Al. Racławickie 14, 20-950 Lublin, e-mail: michal.zawislak@kul.pl. ORCID 0000-0002-0824-5489. 


\section{WSTĘP}

Celem artykułu jest opisanie przebiegu postępowania administracyjnego dotyczącego wniosku o zwrot własności nieruchomości kościelnej należącej do Parafii Polskiego Kościoła Ewangelicznych Chrześcijan Baptystów we Wrocławiu. Przebieg postępowania rewindykacyjnego był wieloetapowy, a na jego bieg wpływ miała nowelizacja art. 4 ustawy z dnia 30 czerwca 1995 r. o stosunku Państwa do Kościoła Chrześcijan Baptystów w Rzeczypospolitej Polskiej (dalej: ustawa) ${ }^{1}$, która zmieniła krąg podmiotów mogących się starać o zwrot utraconych nieruchomości. Ponadto niebagatelny wpływ na przebieg postępowania rewindykacyjnego miał także wyrok Trybunału Konstytucyjnego ${ }^{2}$ w sprawie SK 25/02 dotyczący zgodności z Konstytucją nowelizacji ustawy³. W niniejszej pracy szczególna uwaga zostanie zwrócona na wątpliwości prawne dotyczące zastosowania zmienionego przepisu art. 4 ustawy indywidualnej dotyczącej Kościoła Chrześcijan Baptystów do spraw wszczętych przed nowelizacją. $\mathrm{W}$ artykule zostanie dokonana analiza licznych decyzji administracyjnych wydanych w toku postępowania rewindykacyjnego. Oddzielnej analizie zostaną poddane okoliczności przewlekłości postępowania rewindykacyjnego. Bazę źródłową niniejszego artykułu stanowią przede wszystkim decyzje administracyjne i inne rozstrzygnięcia organów państwowych wydane w toku całego postępowania administracyjnego ${ }^{4}$. Ponadto w artykule wykorzystano niepublikowane wcześniej materiały archiwalne znajdujące się w Archiwum Państwowym we Wrocławiu ${ }^{5}$, Archiwum Akt Nowych

1 Dz. U. z 2015 r. poz. 169.

2 Sentencja opublikowana w Dz. U. z 2005 r. Nr 225, poz. 1939.

3 Ustawa z dnia 26 czerwca 1997 r. o zmianie ustawy o gwarancjach wolności sumienia i wyznania oraz o zmianie niektórych ustaw, Dz. U. z 1998 r. Nr 59, poz. 375.

4 Kopie w posiadaniu autora.

5 Zespół akt archiwalnych o nazwie Urząd Wojewódzki Wrocławski, Archiwum Państwowe we Wrocławiu (dalej: APW). 
w Warszawie ${ }^{6}$ oraz w Archiwum Związku Wolnych Kościołów Ewangelickich w Niemczech? ${ }^{7}$.

\section{HISTORYCZNO-PRAWNE TŁO OSOBOWOŚCI PUBLICZNOPRAWNEJ GMIN BAPTYSTYCZNYCH NA TERENIE ZIEM ZACHODNICH I PÓŁNOCNYCH PRZED DNIEM 8 MAJA 1945 R.}

W ramach rozważań dotyczących postępowania rewindykacyjnego zainicjowanego przez Parafię Polskiego Kościoła Ewangelicznych Chrześcijan Baptystów we Wrocławiu (obecnie Drugi Zbór we Wrocławiu) należy odnieść się do zagadnienia następstwa prawnego związków wyznaniowych działających na terenie Ziem Zachodnich i Północnych, w tym na terenie b. Wolnego Miasta Gdańska. W doktrynie prawa wciąż aktualna jest dyskusja na temat charakteru nabywania dawnych nieruchomości kościelnych na terenie tzw. Ziem Odzyskanych ${ }^{8}$. Zarówno praktyka organów administracji publicznej, jak również orzecznictwo sądów polskich powiela tradycyjną doktrynę wyrażoną w uchwale siedmiu sędziów Sądu Najwyższego z dnia 19 grudnia 1959 r. (sygn. ICO 42/59) bezkrytycznie przyjmując, że jednostki organizacyjne związków wyznaniowych działających na terenie Ziem Zachodnich i Północnych nie mogą być uważane za następców prawnych gdańskich i niemieckich związków wyznaniowych. Odmienne stanowisko wyraził Minister Sprawiedliwości w 2006 r. ${ }^{9}$ Wspo-

6 Zespół akt archiwalnych o nazwie Ministerstwo Administracji Publicznej, Archiwum Akt Nowych w Warszawie (dalej: AAN).

7 Zespół akt archiwalnych o nazwie ,Jahrbuch 1939 des Bundes der Baptistengemeinden in Deutschland“ [,,Rocznik Związku Zgromadzeń Baptystów w Niemczech 1939”], Oncken-Archiv des Bundes Evangelisch-Freikirchlicher Gemeinden in Deutschland K.d.ö.R. z siedzibą w Wustermark w Niemczech.

8 Mazurkiewicz 2006, 221-240; Zieliński 2010, 9-10; Walencik 2010, 186; Krawczyk 2014, 123.

9 Pogląd alternatywny do treści uchwały Sądu Najwyższego z dnia 19 grudnia 1959 r., ICO 42/59 (OSNCK z 1960 r. Nr 2, poz. 33) został zawarty w piśmie Ministra Sprawiedliwości Zbigniewa Ziobry nr DSP-II-5000-105/06 z dnia 21 kwietnia 2006 r. do ks. bp prof. Stanisława Wielgusa współprzewodniczącego Komisji Wspólnej Przedstawicieli Rządu RP i Episkopatu Polski [kopia w posiadaniu autora]. Na treść tego dokumentu urzędowego powołują się: Zieliński, 2010, 10; Walencik 2010, 186. 
mniana uchwała Sądu Najwyższego odnosi się do pojęcia osobowości prawa publicznego. Zgodnie z dekretem z dnia 8 marca 1946 r. o majątkach opuszczonych i poniemieckich ${ }^{10}$ majątek niemieckich i gdańskich osób prawa publicznego przechodził z mocy prawa na własność odpowiednich polskich osób prawnych (art. 2 ust. 4).

Za szczególnie ważne uznać należy omówienie przepisów prawa pruskiego dotyczące zborów baptystycznych na terenie Ziem Zachodnich i Północnych przed dniem 8 maja 1945 r. Omawiana problematyka wykracza poza ramy niniejszego opracowania i zostanie przedstawiona jedynie fragmentarycznie. Jak podaje J. Dziobek-Romański, Kościół Chrześcijan Baptystów na terenie zaboru pruskiego działał w oparciu o przepisy ustawy z dnia 7 lipca 1875 r. o urządzeniu gmin baptystycznych ${ }^{11}$. Przepisy tej ustawy nie są wystarczające do stwierdzenia posiadania osobowości prawa publicznego przez poszczególne gminy baptystyczne działające na terenie Rzeszy Niemieckiej do 8 maja 1945 r. ${ }^{12}$ Kwestia posiadania przez poszczególne wspólnoty religijne, w tym baptystyczne, osobowości prawa publicznego została w sposób precyzyjny określona dopiero na mocy przepisów Konstytucji Weimarskiej. W praktyce status korporacji prawa publicznego zachowały wspólnoty religijne, które istniały, kiedy weszła w życie Konstytucja Weimarska: kościoły ewangeliczne (kościoły regionalne, kongregacje, stowarzyszenia), Kościół rzymskokatolicki (diecezje, parafie, stowarzyszenia, niektóre zakony), poszczególne społeczności żydowskie, dawni katolicy i dawni luteranie, baptyści i menonici. Aktualnie status korporacji na mocy prawa publicznego mają te wspólnoty religijne, które zostały uznane za korporacje na mocy prawa publicznego, kiedy weszła w życie Konstytucja Weimarska (korporacje „urodzone”) ${ }^{13}$ lub którym przyznano ten status na wniosek (korporacje „certyfikowane”) ${ }^{14}$.

Historia Baptystów jest nieodłącznie związana $\mathrm{z}$ powstaniem w Berlinie Wolnego Kościoła Ewangelickiego (Baptystów). To właśnie 28 czerwca 1879 r. kongregacja berlińskich baptystów otrzymała

10 Dz. U. z 1946 r. Nr 13, poz. 87 z późn. zm.

11 Dziobek-Romański 2004, 349.

12 Schultz 1912, 4.

13 „Geborene” Körperschaften.

14 „Gekorene” Körperschaften. 
status korporacji prawa publicznego na podstawie ustawy z dnia 7 lipca 1875 r. Odpowiedź na pytanie, czy gmina baptystyczna we Wrocławiu z siedzibą przy ulicy Martastraße posiadała status korporacji prawa publicznego jest dość złożona i wymaga oddzielnego opracowania ${ }^{15}$.

\section{STATUS PRAWNY POLSKIEGO KOŚCIOŁA EWANGELICZNYCH CHRZEŚCIJAN BAPTYSTÓW}

W okresie dwudziestolecia międzywojennego Baptyści nie mieli uregulowanej sytuacji prawnej i działali na podstawie przepisów pozaborczych. Jak wskazuje K. Krzysztofek, „na ziemiach należących do byłych zaborców baptyści tworzyli nie jeden związek wyznaniowy religijny, ale kilka" ${ }^{\prime \prime}$.

W dniach 24-27 maja 1945 r. w Warszawie odbył się Sobór, na którym powołano do życia Polski Kościół Ewangelicznych Chrześcijan Baptystów ${ }^{17}$. W skład tego Kościoła weszły różne społeczności ewangeliczno-baptystyczne, w tym przedstawiciele Kościoła Wolnych Chrześcijan oraz Związku Słowiańskich Zborów Ewangelicznych Chrześcijan w Polsce ${ }^{18}$. Dodać należy, że w latach 1945-1946 w skład Polskiego Kościoła Ewangelicznych Chrześcijan Baptystów wchodziło także Zjednoczenie Kościołów Chrystusowych ${ }^{19}$. Niezadowoleni z konsolidacji i powstania Polskiego Kościoła Ewangelicznych Chrześcijan Baptystów przedstawiciele Związku Zborów Ewangelicznych Chrześcijan złożyli do Ministerstwa

15 Autor dokonał kwerendy w Archiwum Związku Wolnych Kościołów Ewangelickich w Niemczech. Stosownie do ustaleń zapisanych w „Roczniku Związku Zgromadzeń Baptystów w Niemczech 1939”, Zgromadzenie z Wrocławia I (Marthastr. 20) należało w 1939 r. do Związku Zgromadzeń Baptystów w Niemczech istniejącego od 1849 r. Status korporacji prawa publicznego Związek Zgromadzeń Baptystów w Niemczech, w skład którego wchodził zbór baptystów z Wrocławia, uzyskał 18 sierpnia 1930 r. Zob. „Jahrbuch 1939 des Bundes der Baptistengemeinden in Deutschland“, Oncken-Archiv des Bundes Evang.-Freikirchlicher Gemeinden in Deutschland K.d.ö.R.

16 Krzysztofek 2018, 299-300.

17 Tomaszewski 1991, 43; Winiarczyk-Kossakowska 2004, 292.

18 Kamiński 2012, 37-41.

19 Tomaszewski 1991, 21. 
Spraw Publicznych w styczniu 1946 r. pismo informujące, że to Związek Zborów ,jest jedynym reprezentantem ruchu ewangelicznych chrześcijan w Polsce" 20 .

Powstanie Polskiego Kościoła Ewangelicznych Chrześcijan Baptystów poprzez skonsolidowanie różnych grup ewangeliczno-baptystycznych miało na celu także ochronę miejsc kultu religijnego, w tym ochronę prawną własności obiektów sakralnych ${ }^{21}$. Treść okólnika nr 55 Ministra Administracji Publicznej z dnia 9 marca 1945 r. „majątek prawnie uznanych kościołów nie może być w żadnym wypadku uważany za mienie opuszczone w rozumieniu art. 1 ustawy z dnia 6 maja 1945 o majątkach porzuconych i opuszczonych ${ }^{22}$ nawet $\mathrm{w}$ tym wypadku, gdy większość członków danej gminy wyznaniowej stanowili uprzednio Niemcy, względnie obywatele polscy innej narodowości" stanowiła podstawę do przejmowania przez władze państwowe majątku stanowiącego własność związków wyznaniowych istniejących przed 1939 r. ${ }^{23}$ Zgodnie ze stanowiskiem Ministra Administracji Publicznej wszelki majątek kościelny miał być traktowany jako poniemiecki i podlegać upaństwowieniu na rzecz Skarbu Państwa. W tym okresie władza ludowa w szczególnie dowolny sposób interpretowała prawo, w zgodzie interesami państwa i popieranych przez nie sił politycznych ${ }^{24}$.

Rada Naczelna Polskiego Kościoła Ewangelicznych Chrześcijan Baptystów zwróciła się 16 marca 1946 r. do Ministra Administracji Publicznej o stwierdzenie, że Polski Kościół Ewangelicznych Chrześcijan Baptystów jest publicznoprawnym związkiem religijnym w myśl art. 116 Konstytucji z 17 marca $1921 \mathrm{r}^{25} \mathrm{~W}$ piśmie tym podano, że prośba ta wynikała z konieczności uporządkowania spraw kościelnych zarówno w zakresie

20 Tamże, 61.

21 Starania o odzyskanie kamienicy i kaplicy użytkowanej przez poznańskich baptystów rozpoczął w 1946 r. pastor zboru Jan Pancewicz. Zob. Brzechczyn 2010, 164-177.

22 Dz. U. z 1945 r. Nr 17, poz. 97.

23 Tomaszewski 1991, 46.

$24 \mathrm{Z}$ ponad 114 budynków kościelnych odzyskano zaledwie kilka. Zob. Tomaszewski 1991, 56.

25 Ustawa z dnia 17 marca 1921 r. - Konstytucja Rzeczypospolitej Polskiej, Dz. U. z 1921 r. Nr 44, poz. 267. 
publicznoprawnym, jak i prywatnoprawnym ${ }^{26}$. Minister Administracji Publicznej wstrzymał legalizacje tego związku wyznaniowego z uwagi na negatywny stosunek tego Kościoła do służby wojskowej, co wynikać miało z art. 13 konfesji ${ }^{27}$. W odpowiedzi na ten zarzut Rada Naczelna tego kościoła wystosowała pismo z dnia 2 kwietnia 1946 r. wskazując, że przepis art. 13 konfesji „,stał się nieżyciowym wskutek zmiany poglądów Kościoła na to zagadnienie". Ostatecznie Minister Administracji Publicznej zwrócił się o wydanie opinii przez Chrześcijańską Radę Ekumeniczną na temat relacji Polskiego Kościoła Ewangelicznych Chrześcijan Baptystów z ruchem ewangelicznych chrześcijan i nazwy nowo zorganizowanego Kościoła Baptystów. Odpowiedź tego gremium dla Ministra Administracji Publicznej była następująca: „W obecnej chwili nie istnieją żadne przeszkody natury prawnej, ani teologicznej do załatwienia statutu Kościoła Ewangelicznych Chrześcijan Baptystów z zaprojektowaną nazwą"28.

Minister Administracji Publicznej w dniu 4 maja 1946 r. zalegalizował byt prawny Polskiego Kościoła Ewangelicznych Chrześcijan Baptystów w drodze decyzji administracyjnej ${ }^{29}$. Istotą tej decyzji było stwierdzenie, że Polski Kościół Ewangelicznych Chrześcijan Baptystów został uznany za ,,publicznoprawny związek religijny na zasadzie art. 116 Konstytucji z 17 marca 1921 roku”. W istocie pojawiały się problemy z traktowaniem nowo powstałego związku wyznaniowego jako osoby prawa publicznego vel publicznoprawnego związku religijnego przez władze państwowe niższego szczebla. Rada Polskiego Kościoła Ewangelicz-

26 Pismo Polskiego Kościoła Ewangelicznych Chrześcijan Baptystów do Ministra Spraw Publicznych z dnia 16 marca 1946 r. podpisane przez Prezesa Kościoła Aleksandra Kircunia, AAN, Ministerstwo Administracji Publicznej (dalej: MAP) sygn. 701, s. 36.

$27,[\ldots]$ nie powinno się wywierać przymusu na osobach, które z powodu poważnych skrupułów sumienia, przekonane są, iż oręża w służbie używać nie powinny”. Zob. Tomaszewski 1991, 47.

28 Tomaszewski 1991, 48-49.

29 J. Dziobek-Romański podaje w swojej publikacji błędną sygnaturę (L.V. 2418/46) decyzji o uznaniu Polskiego Kościoła Ewangelicznych Chrześcijan Baptystów za publicznoprawny związek religijny. Por. Dziobek-Romański 2001, 92; Dziobek-Romański 2004, 240-241. Również błędną sygnaturę podaje R. Sztyk (L.V.2433/66). Por. Sztyk 1991, 70. W rzeczywistości decyzja Ministra Administracji Publicznej z dnia 4 maja 1946 r. została oznaczona sygnaturą L.dz. 2433/46, a jej oryginał znajduje się w AAN, MAP sygn. 1071. Zob. Tomaszewski 1991, 48; Winiarczyk-Kossakowska 2004, 295; Krzysztofek 2018, 300. 
nych Chrześcijan Baptystów ponagliła Ministra Administracji Publicznej w dniu 19 września 1947 r., aby decyzja z dnia 4 maja 1946 r. została opublikowana w dzienniku urzędowym Ministra Administracji Publicznej i podana do wiadomości władzom administracji ogólnej ${ }^{30}$. To ponaglenie wynikało m.in. z konieczności obrony praw majątkowych przez poszczególne zbory tego Kościoła na terenie Polski, w szczególności na terenie Ziem Odzyskanych. Na terenie całej Polski, zaraz po wyzwoleniu, baptyści starali się o zwrot obiektów sakralnych będących ich własnością do wybuchu II wojny światowej ${ }^{31}$. Rada Naczelna Polskiego Kościoła Ewangelicznych Chrześcijan Baptystów wystosowała pismo do Okręgowego Urzędu Likwidacyjnego we Wrocławiu powołując się na art. 12 dekretu z dnia 8 marca 1946 r. o majątkach opuszczonych i poniemieckich z prośbą o przyznanie na własność Kościoła budynków w różnych miastach. W tym piśmie Kościół wskazał, że chodzi o kaplice znajdujące się we: Fryborku, Zgorzelicach, Lubaniu, Prudniku, Legnicy i Wrocławiu ${ }^{32}$.

Wobec faktu podporządkowania Polskiego Kościoła Ewangelicznych Chrześcijan Baptystów władzom nowo powstałego Zjednoczonego Kościoła Ewangelicznego ${ }^{33}$, doszło do podjęcia uchwały o skróceniu nazwy

30 Jak podaje K. Krzysztofek, uznanie prawne Polskiego Kościoła Ewangelicznych Chrześcijan Baptystów, choć nastąpiło w dniu 4 maja 1946 r., to publiczne ogłoszenie tej decyzji nastąpiło na mocy pisma okólnego z dnia 21 października 1947 r. w sprawie stanowiska prawnego Polskiego Kościoła Ewangelicznych Chrześcijan Baptystów i Rady Unii Zborów Adwentystów Dnia Siódmego. Zob. Krzysztofek 2018, 299-302.

31 Brzechczyn 2010, 159-181.

32 Pismo Rady Naczelnej Polskiego Kościoła Ewangelicznych Chrześcijan Baptystów do Okręgowego Urzędu Likwidacyjnego z dnia 7 marca 1947 r., APW, Urząd Wojewódzki Wrocławski sygn. VI/688, s. 17. Inne ustalenie co do adresu zboru baptystycznego we Wrocławiu podaje (błędnie cytując z drugiej ręki za Pielka 2018, 139-141) K. Zamirski w swojej publikacji Rewindykacja mienia Kościoła Chrześcijan Baptystów w RP przed Międzykościelna Komisja Regulacyjna - aspekty prawne. Por. Zamirski 2020, 742-743.

33 Zielonoświątkowcy popierali ideę zjednoczenia z innymi ewangelikalnymi ugrupowaniami. Tomaszewski 2009, 19-20; Czajko 2012, 242-243. Prześladowania ze strony władz komunistycznych zmusiły wolnych chrześcijan, ewangelicznych chrześcijan, a po części także zielonoświątkowców do przystąpienia do uznawanego przez władze Zjednoczonego Kościoła Ewangelicznego. Kamiński 2012, 61. Przez cały okres istnienia Zjednoczonego Kościoła Ewangelicznego pozostawał on pod ścisłą kontrolą władz komunistycznych, zaś oficjalna jedność doktrynalna różnych grup religijnych wchodzących w jego skład była sztucznie wytworzona, co powodowało liczne spory. Czajko 2000, 14. 
kościoła na Polski Kościół Chrześcijan Baptystów. Stosowną decyzję podjęto na XV Soborze, który odbywał się w dniach 27-30 maja 1948 r. w Warszawie. O zmianie nazwy Kościoła Ministerstwo Administracji Publicznej zawiadomiło wojewodów, starostów i prezydentów miast stanowiących powiaty grodzkie, w drodze pisma okólnego z dnia 24 sierpnia $1948 \mathrm{r}$. (L.dz. V.M.602/48) ${ }^{34}$.

Dekret z dnia 5 września 1947 r. o uregulowaniu położenia prawnego Kościoła Ewangelicko-Reformowanego w Rzeczypospolitej Polskiej, Kościoła Mariawickiego i Kościoła Starokatolickiego ${ }^{35}$ uchylił na mocy art. 3 pkt 7-9 przepisy rosyjskie i pruskie dotyczące baptystów, ale nie uregulował sytuacji prawnej Polskiego Kościoła Ewangelicznych Chrześcijan Baptystów. Komentarz urzędowy dotyczący sytuacji prawnej Polskiego Kościoła Ewangelicznych Chrześcijan Baptystów przeznaczony dla urzędników administracji państwowej i samorządowej wyjaśniał, że Polski Kościół Ewangelicznych Chrześcijan Baptystów uzyskał „charakter związku religijnego prawnie uznanego na zasadzie reskryptu MAP z 4 maja 1946 r. (L.dz. 2433/46), a więc opierał od tego czasu swój byt prawny na normie prawnej polskiej, nie zaś na przepisach zaborczych"36.

Reasumując, Polski Kościół Ewangelicznych Chrześcijan Baptystów uzyskał status publicznoprawnego związku religijnego na mocy decyzji Ministra Administracji Publicznej z dnia 4 maja 1946 r. W wyniku zmiany składu tego Kościoła i odłączenia się z jego struktur Kościoła Wolnych Chrześcijan i Związku Zborów Ewangelicznych Chrześcijan, a także sporu o używanie słowa „ewangeliczny”, doszło do zmiany nazwy na Polski Kościół Chrześcijan Baptystów ${ }^{37}$. Kontekst próby zjednoczenia wspólnot ewangeliczno-baptystycznych pokazuje dalekowzroczność władz Kościoła i przemyślaną strategię walki o zwrot zabranych przez władze państwowe nieruchomości kościelnych na terenie całego $\mathrm{kraju}^{38}$.

34 Winiarczyk-Kossakowska 2004, 297.

35 Dz. U. z 1947 r. Nr 59, poz. 316.

36 Winiarczyk-Kossakowska 2004, 295-6.

37 Tomaszewski 1991, 64, 71.

38 Pismo Rady Naczelnej Polskiego Kościoła Ewangelicznych Chrześcijan Baptystów do Okręgowego Urzędu Likwidacyjnego z dnia 7 marca 1947 r., APW, Urząd Wojewódzki Wrocławski sygn. VI/688, s. 17. 
Podstawę działalności organizacyjnej Polskiego Kościoła Chrześcijan Baptystów stanowiły przepisy wewnętrzne uchwalone w 1945 r. z uwzględnieniem zmian dokonanych w 1956 r. na XVIII Soborze, aż do 1968 r. Nowy statut został zatwierdzony przez Dyrektora Urzędu do Spraw Wyznań w dniu 30 października 1968 r. (NK-802/9/11/68). Za istotne należy uznać twierdzenie M. Winiarczyk-Kossakowskiej, że zatwierdzenie Statutu Polskiego Kościoła Chrześcijan Baptystów przez Dyrektora Urzędu do Spraw Wyznań na podstawie $\S 2$ pkt 12 uchwały nr 173/65 Rady Ministrów z dnia 10 lipca 1965 r. nie było działaniem legalnym. W stosunku bowiem do Polskiego Kościoła Chrześcijan Baptystów powstała swoista luka prawna, gdyż jego sytuacja prawna określona została na mocy decyzji z 1946 r., a zatem zatwierdzenie Statutu nie należało do kompetencji Urzędu do Spraw Wyznań, który mógł zatwierdzać statuty związków wyznaniowych działających na podstawie prawa o stowarzyszeniach ${ }^{39}$.

Po 1989 r. wraz ze staraniami o uregulowanie sytuacji prawnej w drodze ustawy, Polski Kościół Chrześcijan Baptystów opracował nowe Prawo Wewnętrzne zastępujące dotychczasowy Statut z 1968 r. Nowe Prawo Wewnętrzne weszło w życie 19 października 1991 r. i zmieniło nazwę Kościoła na Kościół Chrześcijan Baptystów w Rzeczypospolitej Polskiej. Następnie zespół roboczy złożony z przedstawicieli Urzędu Rady Ministrów i Kościoła Chrześcijan Baptystów odbył osiem posiedzeń, w wyniku których 5 maja 1993 r. został podpisany protokół przyjęcia projektu ustawy. Ustawa regulująca stosunek Państwa do Kościoła Chrześcijan Baptystów została uchwalona w dniu 30 czerwca $1995 \mathrm{r}^{40}$

\section{PRZEBIEG POSTĘPOWANIA ADMINISTRACYJNEGO} W SPRAWIE ZWROTU PRAWA WŁASNOŚCI

Wnioskiem z dnia 15 listopada 1995 r. Kościół Chrześcijan Baptystów Drugi Zbór we Wrocławiu (dalej: Kościół), będący następcą prawnym Parafii Polskiego Kościoła Ewangelicznych Chrześcijan Baptystów we Wroc-

39 Winiarczyk-Kossakowska 2004, 298.

40 Tekst jedn. Dz. U. z 2015 r. poz. 169. Zob. Winiarczyk-Kossakowska 2004, 303-305, 311. 
ławiu, zwrócił się do Gminy Miejskiej Wrocławia o wszczęcie postępowania w przedmiocie przywrócenia Kościołowi własności upaństwowionej nieruchomości znajdującej się we Wrocławiu. Podstawę prawną wniosku stanowiły przepisy art. 40, 43 i 39 ustawy z dnia 30 czerwca 1995 r. o stosunku Państwa do Kościoła Chrześcijan Baptystów w Rzeczypospolitej Polskiej.

W dniu 4 grudnia 1995 r. Wydział Gospodarki Nieruchomościami Urzędu Miejskiego Wrocławia przekazał niniejszy wniosek (według właściwości) Wojewodzie Wrocławskiemu. W dniu 9 maja 1996 r. Kościół doprecyzował swoje żądanie i zwrócił się już do Wojewody Wrocławskiego z wnioskiem o wydanie decyzji potwierdzającej własność Kościoła w stosunku do następujących nieruchomości: budynku znajdującego się przy ul. Łukasińskiego wraz z nieruchomością gruntową; nieruchomości gruntowej znajdującej się na części działki nr 33/5, AM-9, obręb Południe, pomiędzy kaplicą a budynkiem przy ul. Łukasińskiego. Ponownie jako podstawę prawną wskazano przepisy ustawy z dnia 30 czerwca 1995 r. (art. 4, 39, 40 oraz 41). W dniu 13 czerwca 1996 r. Wojewoda Wrocławski poinformował Kościół o podjętych czynnościach zmierzających do załatwienia sprawy, natomiast pismem z dnia 6 września 1996 r. skierowanym do Urzędu Miejskiego we Wrocławiu zwrócił się o niepodejmowanie działań zmierzających do zmiany statusu prawnego nieruchomości lub jej częśsi ${ }^{41}$.

Wojewoda Wrocławski decyzją z dnia 12 września 1996 r. odmówił przywrócenia Kościołowi prawa własności nieruchomości położonej we Wrocławiu przy ul. Łukasińskiego ${ }^{42}$. Od powyższej decyzji Kościół złożył odwołanie do Ministra-Szefa Urzędu Rady Ministrów. Minister odpowiedział pismem z dnia 1 lipca 1998 r. wyjaśniając, że długość postępowania, od listopada 1995 r. do lipca 1998 r., wynikała ze zmian legislacyjnych wprowadzonych do ustawy z dnia 30 czerwca 1995 r. na mocy ustawy z dnia 26 czerwca 1997 r. o zmianie ustawy o gwarancjach wolności sumienia i wyznania oraz o zmianie niektórych ustaw, która weszła w życie z dniem 30 maja 1998 r. Minister jednocześnie zobowiązał organ I instan-

41 Pismo Wojewody Wrocławskiego z dnia 6 września 1996 r., sygn. SO/II/5710/52/96.

42 Decyzja Wojewody Wrocławskiego z dnia 12 września 1996 r., sygn. SO/ II/5710/1264/42/56/96. 
cji do wydania decyzji do dnia 15 sierpnia 1998 r. Terminu tego nie dotrzymano, w związku z czym dnia 12 stycznia 1999 r. Kościół wniósł skargę do Naczelnego Sądu Administracyjnego w przedmiocie bezczynności, która trwała (na dzień złożenia skargi) od listopada 1995 r. do marca 1999 roku.

Dopiero dnia 5 marca 1999 r. Minister Spraw Wewnętrznych i Administracji (dalej: MSWiA) wydał decyzję uchylającą decyzję Wojewody Wrocławskiego z dnia 12 września 1996 r. i nakazał, aby przy ponownym rozpatrywaniu sprawy Wojewoda uwzględnił także zmieniony art. 4 ustawy. Dnia 29 maja 1999 r. Wojewoda zwrócił się do MSWiA o dokonanie oficjalnej wykładni zmienionego art. 4 ustawy „w związku z licznymi wątpliwościami co do właściwej interpretacji tego przepisu". Dnia 20 czerwca 2000 r. Minister odpowiedział, że w związku z tym, iż organy administracyjne były związane przepisami prawa obowiązującymi w dniu wydania decyzji, nie ma znaczenia, czy pierwotny wniosek Kościoła został złożony w czasie, kiedy art. 4 ustawy miał inne brzmienie ${ }^{43}$.

Dnia 7 grudnia 2000 r. Kościół wniósł skargę w przedmiocie bezczynności trwającej od listopada 1995 r. do marca 1999 r., do Naczelnego Sądu Administracyjnego (dalej: NSA), który nakazał Wojewodzie Dolnośląskiemu wydanie decyzji co do istoty sprawy w terminie trzydziestu dni. Dnia 21 czerwca 2002 r. Wojewoda wydał decyzję i odmówił zwrotu przedmiotowej nieruchomości, od której to decyzji Kościół się odwołał. Dnia 23 września 2002 r. Minister Spraw Wewnętrznych i Administracji uchylił zaskarżoną decyzję i skierował sprawę do ponownego rozpatrzenia przez Wojewodę. Dnia 23 lutego 2003 r. Kościół złożył zażalenie do Wojewody w przedmiocie opóźnienia w postępowaniu. Dnia 8 lutego 2007 r. Wojewoda wydał postanowienie, w którym stwierdził, że z uwagi na szczególnie złożony charakter sprawy, decyzja co do istoty sprawy nie mogła zostać wydana w terminach ustawowych i jako nowy termin wydania decyzji wyznaczył 30 czerwca $2007 \mathrm{r}^{44}$

Wojewoda Dolnośląski w dniu 18 czerwca 2007 r. wydał decyzję co do istoty sprawy i odmówił zwrotu przedmiotowej nieruchomości. Przy wy-

43 Decyzja Ministra Spraw Wewnętrznych i Administracji z dnia 5 marca 1999 r., sygn. WP.-3621/XII/84/96/EM.

44 Decyzja Wojewody Dolnośląskiego z dnia 8 lutego 2007 r., sygn. SP.4.RR. II.7721-104/01. 
dawaniu decyzji Wojewoda uwzględnił treść znowelizowanego art. 4 ustawy oraz wskazania płynące z wyroku Trybunału Konstytucyjnego w sprawie SK 25/02 i stwierdził, że Kościół nie spełniał wymogów określonych w tym przepisie, tj. nie może być następcą prawnym Kościoła, który nie działał na terytorium Polski przed 1 września 1939 r. W związku z niekorzystną dla Kościoła treścią decyzji złożono od niej odwołanie. Dnia 6 lutego 2008 r. MSWiA podtrzymał zaskarżoną decyzję w mocy, zaś Kościół w ustawowym terminie wniósł skargę do Wojewódzkiego Sądu Administracyjnego w Warszawie. Dnia 12 września 2008 r. WSA w Warszawie oddalił skargę na mocy wyroku z dnia 12 września 2008 r. ${ }^{45}$, od którego Kościół wniósł skargę do NSA. W dniu 13 października 2009 r. Naczelny Sąd Administracyjny oddalił skargę kasacyjną Kościoła. Tym samym wyrok stał się prawomocny i ostateczny ${ }^{46}$.

Reasumując, przebieg postępowania w sprawie o zwrot własności nieruchomości utraconej przez parafię Polskiego Kościoła Ewangelicznych Chrześcijan Baptystów we Wrocławiu trwał ponad 13 lat. Pierwsza decyzja w sprawie została wydana w 1996 r., druga decyzja organu II instancji została wydana w marcu 1999 r., po blisko 3,5 roku prowadzenia postępowania odwoławczego. W tym czasie nastąpiła zmiana art. 4 ustawy z dnia 30 czerwca 1995 r., która weszła w życie 30 maja 1998 r. Trzecia decyzja w sprawie - w toku ponownego rozpatrzenia sprawy - została wydana przez organ I instancji po 3 latach i 2 miesiącach (od marca 1999 r. do maja 2002 r.). Czwarta decyzja wydana przez organ II instancji została wydana 23 września 2002 r. Była to decyzja uchylająca decyzję organu I instancji i nakazująca ponowne rozpatrzenie sprawy. Na tym etapie znowu pojawił się problem przewlekłości postępowania administracyjnego, gdyż organ I instancji wydał piątą decyzję w dniu 18 czerwca 2007 r., zatem po ponad 4,5 roku prowadzenia postępowania administracyjnego. Przewlekłość została potwierdzona przez organy administracji w toku kontroli instancyjnej decyzji dotyczą-

45 Wyrok Wojewódzkiego Sądu Administracyjnego z dnia 12 września 2008 r., sygn. akt I SA/Wa 568/08.

46 Wyrok NSA z dnia 13 października 2009 r., sygn. akt II OSK 33/09. 
cych zwrotu prawa własności, a także przez wyrok Europejskiego Trybunału Praw Człowieka z dnia 15 kwietnia $2018 \mathrm{rr}^{47}$

Samo postępowanie w sprawie zwrotu własności kościelnej nieruchomości należącej do Polskiego Kościoła Ewangelicznych Chrześcijan Baptystów można podzielić na kilka etapów. Pierwszy etap obejmuje postępowanie od momentu złożenia wniosku przez Kościół we wrześniu 1996 r. aż do momentu nowelizacji art. 4 ustawy, która weszła w życie w 1998 r. Drugi etap postępowania był związany z wydaniem wyroku przez Trybunał Konstytucyjny w sprawie SK 25/02 w związku ze skargą dotyczącą stwierdzenia niezgodności art. 7 pkt 1 ustawy z dnia 26 czerwca 1997 r. o zmianie ustawy o gwarancjach wolności sumienia i wyznania oraz o zmianie niektórych ustaw z art. 2, 64 ust. 2 Konstytucji RP ${ }^{48}$. Ostatni etap postępowania w sprawie zwrotu własności nieruchomości to etap wydania decyzji przez Wojewodę Dolnośląskiego o odmowie przyznania prawa własności i utrzymania jej w mocy przez właściwego ministra ${ }^{49}$. Następnie wyrok WSA w Warszawie i NSA kończący sprawę merytorycznie ${ }^{50}$.

5. NOWELIZACJA ART. 7 PKT 1 USTAWY Z DNIA 26 CZERWCA 1997 R. O ZMIANIE USTAWY O GWARANCJACH WOLNOŚCI SUMIENIA I WYZNANIA ORAZ O ZMIANIE NIEKTÓRYCH USTAW

Kościół Chrześcijan Baptystów, od momentu wejścia w życie ustawy z dnia 30 czerwca 1995 r. o stosunku Państwa do Kościoła Chrześcijan Baptystów w Rzeczypospolitej Polskiej posiadał ekspektatywę wynikającą z ówczesnego brzmienia art. 4 ustawy. Kościół Chrześcijan Baptystów

47 Judgment of 5 April 2018 of Christian Baptist Church in Wrocław v. Poland (Application no. 32045/10). [Wyrok z 5 kwietnia 2018 r. Kościół Chrześcijan Baptystów we Wrocławiu przeciwko Polsce (skarga nr 32045/10)]. Wyrok wydano w języku angielskim.

48 Wyrok Trybunału Konstytucyjnego z dnia 8 listopada 2005 r., sygn. akt SK 25/02. Dz. U. z 2005 r. Nr 225, poz. 1939.

49 Decyzja Wojewody Dolnośląskiego z dnia 18 czerwca 2007 r., sygn. SP.4.RR. II.7721-104/01; decyzja Ministra Spraw Wewnętrznych i Administracji z dnia 6 lutego 2008 r., sygn. DWRMNiE-6780-35/07/JB.

50 Wyrok Wojewódzkiego Sądu Administracyjnego z dnia 12 września 2008 r., sygn. akt I SA/Wa 568/08; Wyrok NSA z dnia 13 października 2009 r., sygn. akt II OSK 33/09. 
będąc następcą prawnym zborów, organizacji i gmin baptystycznych działających na obecnym terytorium Rzeczypospolitej Polskiej, miał w myśl art. $40 \mathrm{w}$ związku $\mathrm{z}$ art. $39 \mathrm{i}$ art. 4 ustawy prawną podstawę domagania się rewindykacji nieruchomości stanowiących własność Kościoła Chrześcijan Baptystów przed 1 września 1939 r., także położonych na terytorium tzw. Ziem Odzyskanych.

Zmiany dotyczące domagania sięrewindykacjinieruchomości stanowiących własność Kościoła Chrześcijan Baptystów przed 1 września 1939 r. zostały uregulowane w art. 7 ustawy z dnia 26 czerwca 1997 r. o zmianie ustawy o gwarancjach wolności sumienia i wyznania oraz o zmianie niektórych ustaw (dalej: ustawa nowelizująca). Zmiany te, oprócz omówionej nowelizacji art. 4 ustawy, dotyczyły między innymi: wprowadzenia możliwości rozpoznania wniosków wniesionych przez kościelne osoby prawne w trybie art. 40 ustawy, w stosunku do których nie zostały zakończone postępowania administracyjne, w postępowaniu regulacyjnym określonym w dziale IIIa ustawy z dnia 17 maja 1989 r. o gwarancjach wolności sumienia i wyznania ${ }^{51}$; oraz przedłużenia terminu, w jakim mogły być składane wnioski o nieodpłatne przekazanie nieruchomości, o których mowa w art. 43 ustawy $^{52}$.

Sytuacji Kościoła dotyczył również art. 14 ustawy nowelizującej, który przewidywał przeniesienie postępowania w sprawie przywrócenia własności nieruchomości z postępowania administracyjnego do postępowania przed Międzykościelną Komisją Regulacyjną. Przepisy ustawy nowelizującej w 1997 r. zagwarantowały osobom prawnym Polskiego Autokefalicznego Kościoła Prawosławnego, Kościoła Ewangelicko-Reformowanego oraz Kościoła Chrześcijan Baptystów prawo do wystąpienia w terminie 3 miesięcy od dnia wejścia w życie ustawy nowelizującej (do 30 sierpnia 1998 r.) z wnioskiem o wszczęcie postępowania regulacyjnego. Kolejna nowelizacja ustawy o gwarancjach wolności sumienia i wyznania z 2004 r. ${ }^{53}$ prze-

51 Art. 7 pkt 6 ustawy z dnia 26 czerwca 1997 r. o zmianie ustawy o gwarancjach wolności sumienia i wyznania oraz o zmianie niektórych ustaw dodający art. 42a do ustawy z dnia 30 czerwca 1995 r. o stosunku Państwa do Kościoła Chrześcijan Baptystów w Rzeczypospolitej Polskiej.

52 Art. 7 pkt 7 ustawy z dnia 26 czerwca 1997 r. o zmianie ustawy o gwarancjach wolności sumienia i wyznania oraz o zmianie niektórych ustaw.

53 Dz. U. z 2004 r. Nr 145, poz. 1534. 
dłużyła ten termin o kolejne dwa lata (do 10 lipca 2006 r.). Sposób przedłużenia terminów zgłaszania wniosków regulacyjnych został wprowadzony z pogwałceniem przesłanek art. 25 ust. 5 Konstytucji RP ${ }^{54}$.

Poselski projekt ${ }^{55}$ ustawy z dnia 26 czerwca 1997 r. o zmianie ustawy o gwarancjach wolności sumienia i wyznania oraz o zmianie niektórych ustaw w odniesieniu do Kościoła Chrześcijan Baptystów przewidywał prowadzenie postępowania przed Komisjami Regulacyjnymi w sprawie zwrotu utraconych po 1945 r. nieruchomości kościelnych (art. 5 pkt 1-5 projektu). Żadna z proponowanych w projekcie zmian w ustawie o stosunku Państwa do Kościoła Chrześcijan Baptystów nie dotyczyła art. 4 tej ustawy. Z dyskusji przeprowadzonej podczas I czytania wynikało, że treść projektu w tym kształcie została uzgodniona z zainteresowanymi kościołami ${ }^{56}$.

Zmiana dotycząca art. 4 ustawy o stosunku Państwa do Kościoła Chrześcijan Baptystów pojawiła się w sprawozdaniu dwu połączonych komisji: Administracji i Spraw Wewnętrznych oraz Komisji Ustawodawczej, które odbyły wspólne posiedzenie 18 lutego 1997 r. ${ }^{57}$ Przedstawiciel Kościoła Chrześcijan Baptystów w piśmie z dnia 3 maja 1997 r. wyraził sprzeciw wobec nowelizacji ustawy dotyczącej tego Kościoła. Komisje zaakceptowały przedłożoną przez podkomisję poprawkę zawartą w art. 7 pkt 1 projektu ustawy. Poprawka głosiła, że: ,,art. 4 otrzymuje brzmienie: Kościół i jego osoby prawne są następcami prawnymi zborów, organizacji i gmin baptystycznych działających na terytorium Rzeczypospolitej Polskiej przed dniem 1 września 1939 r.” W trakcie wspólnego posiedzenia obu komisji nie zgłoszono żadnych uwag do proponowanej treści art. 7 pkt 1 projektu ustawy nowelizującej. Także w toku dalszych prac legislacyjnych nie zgłaszano uwag ani poprawek dotyczących omawianego przepisu ${ }^{58}$.

Z akt skargi konstytucyjnej wynika, że w piśmie z dnia 12 czerwca $1997 \mathrm{r}$. skierowanym do Marszałka Sejmu Rada Kościoła wniosła „zdecydowa-

54 Borecki 2007, 149-150; Walencik 2007, 67-85.

55 Druk sejmowy nr 1680 z 23 kwietnia 1996 r.

56 Zob. Sprawozdanie stenograficzne z 80. posiedzenia Sejmu w dniu 31 maja 1996 r., s. 278.

57 Zob. Druk sejmowy nr 2174 z 18 lutego 1997 r.

58 Zob.SprawozdaniestenograficzneSejmuzposiedzenianr 110wdniu25czerwca 1997r. - II i III czytanie, posiedzenie nr 114 w dniu 28 sierpnia 1997 r. - głosowanie nad uchwałą Senatu. 
ny sprzeciw" przeciwko zmianie proponowanej treści art. 7 pkt 1 projektu ustawy nowelizującej ${ }^{59}$. Trybunał Konstytucyjny w wyroku z dnia 8 listopada 2005 r. (sygn. akt SK 25/02) stwierdził, że z punktu widzenia zasad trybu legislacyjnego złożenie sprzeciwu przez Radę Kościoła nie obligowało ustawodawcy do jego uwzględnienia. Wręcz przeciwnie, jest dowodem na to, że Kościół Chrześcijan Baptystów miał możliwość ustosunkowania się do zmian proponowanych w dotyczącej go ustawie, w tym do zmiany dotyczącej art. 4 ustawy. Ponadto w posiedzeniach podkomisji nadzwyczajnej, powołanej przez Sejm w styczniu 1997 r., procedującej nad zmianami do ustawy o stosunku Państwa do Kościoła Chrześcijan Baptystów w RP, brali udział przedstawiciele zainteresowanych Kościołów, którzy mieli pełną możliwość dyskusji i wyrażania opinii w sprawach ich dotyczących. Istotnym problemem, który następnie został wskazany jako jeden z zarzutów skargi konstytucyjnej dotyczącej zmiany art. 4 ustawy dokonanej przez art. 7 pkt 1 ustawy nowelizującej, było naruszenie art. 1 pkt 3 ustawy z dnia 30 czerwca 1995 r. ,Wszelkie zmiany niniejszej ustawy wymagają uprzedniej opinii Prezydium Rady Kościoła”. Trybunał Konstytucyjny w sprawie SK 25/02 uznał, że Kościół Chrześcijan Baptystów miał możliwość wyrażenia uprzedniej opinii, która nie mogła mieć jednak charakteru wiążącego dla Sejmu przy zmianie treści art. 4 ustawy ${ }^{60}$.

Kościołowi Chrześcijan Baptystów i jego osobom prawnym zgodnie z pierwotnym brzmieniem art. 4 ustawy przyznane zostało następstwo prawne zborów, organizacji i gmin baptystycznych, które działały na terytorium, pozostającym przed 1 września 1939 r. poza ówczesnymi granicami Polski. Warto odnotować, że jedynie ustawa z dnia 30 czerwca 1995 r. o stosunku Państwa do Kościoła Ewangelicko-Metodystycznego w Rzeczypospolitej Polskiej ${ }^{61}$ zawierała regulację o następstwie prawnym podobną do tej, którą posiadał Kościół Chrześcijan Baptystów.

59 Skarga konstytucyjna Okręgu Gdańskiego Kościoła Chrześcijan Baptystów, s. 3 [kopia w posiadaniu autora].

${ }^{60}$ Wyrok Trybunału Konstytucyjnego z dnia 8 listopada 2005 r., sygn. akt SK 25/02, s. $9-11$.

${ }^{61}$ Art. 4. Kościół i jego osoby prawne są następcami prawnymi parafii i organizacji metodystycznych działających na obecnym terytorium Rzeczypospolitej Polskiej przed dniem 1 września 1939 r. Tekst jedn. Dz. U. z 2014 r. poz. 1712 z późn. zm. 
Dzięki uchwalonej nowelizacji art. 4 ustawy, żadna z ustaw regulujących stosunek Państwa do związków wyznaniowych nie przewidywała możliwości przywrócenia kościołom własności upaństwowionych nieruchomości położonych na Ziemiach Zachodnich i Północnych. Na skutek zmiany wprowadzonej przez przepis art. 7 pkt 1 ustawy nowelizującej, zmienione zostało - jak wspomniano - brzmienie art. 4 ustawy. Zmieniono krąg podmiotów, wyłączając $\mathrm{z}$ tego kręgu jednostki organizacyjne, które przed 1 września 1939 r. działały na terenach Ziem Zachodnich i Północnych, wchodzących wówczas w skład terytorium III Rzeszy Niemieckiej. Nowelizacja art. 4 ustawy spowodowała dalej idący skutek niż tylko ten związany ze zmianą zakresu terytorialnego zastosowania rewindykacji. Z uwagi na fakt braku przepisów przejściowych, wiele postępowań administracyjnych o zwrot upaństwowionej nieruchomości kościelnej oznaczało, iż w tych samych, niezmienionych okolicznościach faktycznych, Kościół i jego osoby prawne pozbawione zostały przyznanej uprzednio możliwości dochodzenia swoich praw w zakresie zwrotu znacjonalizowanego mienia. Również ta kwestia związana z omawianą powyżej nowelizacją art. 4 ustawy była przedmiotem zarzutów skargi konstytucyjnej złożonej przez Okręg Gdański Kościoła Chrześcijan Baptystów. Trybunał Konstytucyjny stwierdził, że nowelizacja art. 4 ustawy z dnia 30 czerwca 1995 r. spowodowała wprowadzenie w sporach o przywrócenie własności nieruchomości (lub ich części), na obszarach Ziem Zachodnich i Północnych, przyłączonych do Polski po II wojnie światowej, jednolitej i równoprawnej dla wszystkich kościołów i związków wyznaniowych regulacji prawnej ${ }^{62}$.

Reasumując, przepis art. 4 ustawy, w brzmieniu obowiązującym przed jego zmianą dokonaną przepisami ustawy nowelizującej, stanowił, obok art. 4 ustawy z dnia 30 czerwca 1995 r. o stosunku Państwa do Kościoła Ewangelicko-Metodystycznego, regulację wyjątkową. Żadna z innych ustaw o stosunku państwa do poszczególnych związków wyznaniowych nie uznawała następstwa prawnego kościelnych osób prawnych na Ziemiach Zachodnich i Północnych. Trybunał Konstytucyjny stwierdzając zgodność art. 7 pkt 1 ustawy nowelizującej z art. 2 i art. 64 ust. 2 Konstytucji RP doprowadził do niekorzystnych rozstrzygnięć administracyjnych

62 Wyrok Trybunału Konstytucyjnego z dnia 8 listopada 2005 r., sygn. akt SK 25/02, s. 12 . 
w zakresie przyznawania prawa własności utraconych nieruchomości kościelnych, w tym także w odniesieniu do sprawy nieruchomości kościelnej, której zwrotu domagał się Drugi Zbór we Wrocławiu.

\section{POSTEPOWANIE ADMINISTRACYJNE PO NOWELIZACJI ART. 4 USTAWY}

Wraz z nowelizacją art. 4 ustawy nie została wprowadzona regulacja normująca załatwianie spraw związanych z wnioskami kościelnych osób prawnych, złożonymi w trybie art. 40 ustawy, a nierozpoznanymi do dnia utraty mocy obowiązującej w jej pierwotnym brzmieniu i dotyczącymi nieruchomości położonych na Ziemiach Zachodnich i Północnych, tzn. nieruchomości należących do podmiotów, które nowelizacja wykluczyła z kręgu poprzedników prawnych Kościoła Chrześcijan Baptystów i jego osób prawnych.

Wobec braku regulacji przejściowej związanej ze zmianą kręgu poprzedników prawnych Kościoła i jego osób prawnych pojawiło się zagadnienie kontynuacji prowadzenia dotychczasowego postępowania w sprawie z wniosku Drugiego Zboru Kościoła Chrześcijan Baptystów we Wrocławiu. Z uwagi na powyższe, Minister Spraw Wewnętrznych i Administracji na mocy decyzji z dnia 5 marca 1999 r. uchylił decyzję Wojewody Wrocławskiego z dnia 12 września 1996 r. w całości i przekazał sprawę do ponownego rozpatrzenia ${ }^{63}$. Konieczność uchylenia decyzji wymuszona była treścią znowelizowanego przepisu art. 4 ustawy, który istotnie zmienił krąg podmiotów legitymowanych do wystąpienia ze skutecznym wnioskiem rewindykacyjnym ${ }^{64}$.

Jednocześniewrazzuchyleniemdecyzjizdnia12 września 1996r.nastąpiła bogata korespondencja dotycząca próby polubownego załatwienia sprawy zwrotu nieruchomości kościelnej. W piśmie z dnia 25 listopada 1999 r. Wojewoda Dolnośląski zwrócił się do Prezydenta Miasta Wrocławia, jako wykonującego zadania starosty, m.in. o zajęcie stanowiska w kwestii możliwości

63 Decyzja Ministra Spraw Wewnętrznych i Administracji z dnia 5 marca 1999 r., sygn. WP.3621/XII/84/96/EM.

64 Ustawa z dnia 26 czerwca 1997 r. o zmianie ustawy o gwarancjach wolności sumienia i wyznania oraz o zmianie niektórych ustaw. 
przyznania Kościołowi innej nieruchomości w zamian za nieruchomość położoną przy ul. Łukasińskiego. Pismem z dnia 24 marca 1999 r. (doręczonym Kościołowi 3 kwietnia 2000 r.) Wojewoda Dolnośląski zwrócił się do Urzędu Miejskiego we Wrocławiu o zajęcie stanowiska w kwestii przyznania Kościołowi innej nieruchomości w zamian za nieruchomość położoną we Wrocławiu przy ul. Łukasińskiego. Pismem z dnia 29 maja 2000 r. Wojewoda Dolnośląski zwrócił się do Ministra Spraw Wewnętrznych i Administracji z zapytaniem prawnym dotyczącym interpretacji art. 4 ustawy ${ }^{65}$.

Wymiana korespondencji w latach 1999-2002, o której mowa powyżej, spowodowała zwłokę w wydaniu decyzji rewindykacyjnej. Pismem z dnia 21 lipca 2000 r. do Dolnośląskiego Urzędu Wojewódzkiego wpłynął wniosek o usunięcie naruszenia prawa polegającego na zwłoce w wydaniu decyzji w przedmiotowej sprawie. W dniu 26 października 2000 r. Kościół złożył zażalenie skierowane do Ministra Spraw Wewnętrznych i Administracji na bezczynność Wojewody Dolnośląskiego wobec niewydania przez ten organ decyzji w rozpatrywanej sprawie i nieusprawiedliwienia zwłoki w jej wydaniu. W dniu 11 grudnia 2000 r. Kościół złożył skargę do Naczelnego Sądu Administracyjnego w Warszawie na bezczynność Wojewody Dolnośląskiego. W uzasadnieniu skargi podano, że pomimo złożenia zażalenia do Ministra w dniu 26 października 2000 r. organ nadal nie wydał decyzji w sprawie objętej wnioskiem. Postanowieniem z dnia 1 marca 2001 r. Minister Spraw Wewnętrznych i Administracji uznał zażalenie za uzasadnione i wyznaczył termin załatwienia sprawy do dnia 30 kwietnia 2001 r. oraz zarządził wyjaśnienie przyczyn i ustalenie winnych niezałatwienia sprawy w terminie ${ }^{66}$. Wojewoda Dolnośląski ocenił zarzuty o jego bezczynności za chybione, zaś Kościół w piśmie do NSA z dnia 4 lipca 2001 r. wskazał, że Wojewoda Dolnośląski nie zastosował się do postanowienia Ministra z dnia 1 marca 2001 r. i nie wydał decyzji w terminie wskazanym, czyli do stycznia 2002 r. NSA na mocy wyroku z dnia 12 marca 2002 r. zobowiązał Wojewodę Dolnośląskiego do wydania decyzji w terminie 30 dni od daty

65 Pismo Wojewody Dolnośląskiego do Ministra Spraw Wewnętrznych i Administracji z dnia 29 maja 2000 r. Zob. Wyrok Wojewódzkiego Sądu Administracyjnego w Warszawie z dnia 12 września 2008 r., sygn. akt ISA/Wa 568/08.

${ }^{66}$ Postanowienie Ministra Spraw Wewnętrznych i Administracji z dnia 1 marca 2001 r., sygn. WP.0212/97/2000. 
doręczenia wyroku, ponadto zasądził od Wojewody Dolnośląskiego na rzecz skarżącego zwrot kosztów postępowania ${ }^{67}$. Wojewoda Dolnośląski wydał stosowną decyzję w dniu 21 czerwca $2002 \mathrm{r}^{68}$

Decyzja Wojewody Dolnośląskiego z dnia 21 czerwca 2002 r. była pierwszą decyzją merytoryczną uwzględniającą nowelizację art. 4 ustawy. Wojewoda Dolnośląski odmówił przywrócenia Kościołowi nieruchomości położonej we Wrocławiu przy ul. Łukasińskiego 20, tj. budynku znajdującego się przy ul. Łukasińskiego 20 wraz z nieruchomością gruntową; nieruchomości gruntowej, znajdującej się na części działki nr 33/5, AM-9, obręb Południe, pomiędzy kaplicą a budynkiem przy ul. Łukasińskiego, a także przyznania odpowiedniej nieruchomości zamiennej. W uzasadnieniu Wojewoda przytoczył szczegółowo przebieg dotychczasowego postępowania w przedmiocie przywrócenia Kościołowi własności upaństwowionej nieruchomości ${ }^{69}$. Wojewoda stwierdził, że od spełnienia przesłanki wymienionej w art. 39 ust. 1 pkt 1, tj. władania osób prawnych, o których mowa w art. 4 ustawy, uzależnione jest przywrócenie własności nieruchomości. W rozumieniu znowelizowanego art. 4 ustawy Kościół Chrześcijan Baptystów i jego osoby prawne są następcami prawnymi zborów, organizacji i gmin baptystycznych działających na terytorium Rzeczypospolitej Polskiej przed dniem 1 września 1939 r. Następstwo prawne nie obejmuje więc terytorium, które przed dniem 1 września 1939 r. nie wchodziło w skład Państwa Polskiego. Stanowisko powyższe znalazło odzwierciedlenie w opinii prawnej Ministra Spraw Wewnętrznych i Administracji z dnia 20 czerwca 2000 r., w której Minister stwierdza, że następstwo prawne, o którym mowa w art. 4 ustawy, obejmuje jedynie terytorium Rzeczypospolitej Polskiej przed 1 września 1939 r. ${ }^{70}$ Wojewoda uzasadniając odmowę przyznania prawa własności wskazał również, że Wojewoda Wrocławski w dniu 4 września 1946 r. oddawał w zarząd Polskiego Kościoła Ewangelicznych Chrześcijan Baptystów kościół przy

67 Wyrok Naczelnego Sądu Administracyjnego z dnia 12 marca 2002 r., sygn. akt II SAB/Wr 20/2001.

68 Decyzja Wojewody Dolnośląskiego z dnia 21 czerwca 2002 r., sygn. NGK. VII.7721-104/01.

69 Tamże.

70 Opinia prawna Ministra Spraw Wewnętrznych i Administracji z dnia 20 czerwca 2000 r., sygn. WP.0267/7/2000. 
ul. Łukasińskiego 20 wraz z posesją przynależną do tego Kościoła. Niemniej jednak dla ww. nieruchomości na wniosek Kościoła z dnia 6 marca 1956 r. urządzono księgę wieczystą KW 945, zaś w dziale II tej księgi wieczystej jako podstawę nabycia wskazano decyzję Wojewody Wrocławskiego z dnia 4 września 1946 r. oraz zaświadczenie Prezydium Miejskiej Rady Narodowej we Wrocławiu z dnia 3 grudnia 1955 r. $^{71}$

Wskutek odwołania Kościoła od decyzji Wojewody Dolnośląskiego z dnia 21 czerwca 2002 r. Minister Spraw Wewnętrznych i Administracji uchylił zaskarżoną decyzję w całości i przekazał sprawę do ponownego rozpatrzenia przez organ I instancji. W uzasadnieniu decyzji z dnia 23 września 2002 r. ${ }^{72}$ Minister szczegółowo uzasadnił istotę dotychczasowego postępowania rewindykacyjnego wraz $\mathrm{z}$ zaistniałymi naruszeniami po stronie organów. Minister uznał odwołanie od decyzji Wojewody Dolnośląskiego z dnia 21 czerwca 2002 r. za zasługujące na uwzględnienie w całości. Minister uznał, że ocena następstwa prawnego wynikająca z art. 4 ustawy z dnia 30 czerwca 1995 r., zmienionego przepisem art. 7 pkt 1 ustawy z dnia 26 czerwca 1997 r. o zmianie ustawy o gwarancjach wolności sumienia i wyznania oraz o zmianie niektórych ustaw, w zakresie wspomnianego następstwa po gminie baptystycznej działającej we Wrocławiu przed rokiem 1945 jest zbędna. Z akt sprawy wynikało bowiem, że przedmiotowa nieruchomość po 1945 r. została wpisana do księgi wieczystej jako własność parafii Polskiego Kościoła Ewangelicznych Chrześcijan Baptystów we Wrocławiu. Zdaniem Ministra, ocena dokumentów stanowiących podstawę wpisu w księdze wieczystej, a w konsekwencji kwestionowanie prawidłowości wpisu, wykracza poza kompetencje organu administracji publicznej. Zgodnie z art. 3 ust. 1 ustawy z dnia 6 lipca 1982 r. o księgach wieczystych i hipotece domniemywa się, że prawo jawne z księgi wieczystej jest wpisane zgodnie z rzeczywistym stanem prawnym. Minister wskazał w tym przypadku, że jeśli dokumenty stanowiące podstawę wpisu prawa własności w księdze wieczystej są kwestionowane, prawidłowość tego wpisu można ustalić jedynie w try-

71 Decyzja Wojewody Dolnośląskiego z dnia 21 czerwca 2002 r., sygn. NGK. VIII.7721-104/01.

72 Decyzja Ministra Spraw Wewnętrznych i Administracji z dnia 23 września 2002 r., sygn. WP.6780/23/02. 
bie dopuszczającym możliwość uzgodnienia treści księgi wieczystej z rzeczywistym stanem prawnym ${ }^{73}$.

Minister odniósł się również do zarzutu, że decyzja Wojewody Wroclawskiego z dnia 4 września 1946 r. oraz zaświadczenie prezydium Miejskiej Rady Narodowej z dnia 3 grudnia 1955 r. i pismo Okręgowego Urzędu Likwidacyjnego stanowiły o tym, że przedmiotowa nieruchomość została oddana w zarząd, a nie na własność Kościołowi. Minister stwierdził, że Wojewoda w decyzji z dnia 4 września 1946 r. określił, że „na podstawie [...] dekretu z dnia 8 marca 1946 r. o majątkach opuszczonych i poniemieckich /Dz.U.R.P. Nr 13 art. 2 punkt 4/ - oddaje w zarząd [...], a zatem wojewoda w swojej decyzji przywołał art. 2 wspomnianego dekretu". Minister przekonująco zauważył, że z ustępu 4 art. 2 dekretu wynika, że ,„[...] majątek niemieckich i gdańskich osób prawnych prawa publicznego przechodzi z mocy samego prawa na własność odpowiednich polskich osób prawnych”, a art. 12 ust. 1 tego dekretu stanowi, że „okręgowy urząd likwidacyjny [...] przekazuje majątki przechodzące $\mathrm{z}$ mocy prawa art. 2 [...] ust. 4 na własność [...] osób prawnych prawa publicznego, w zarząd [...] organom osób prawnych prawa publicznego".

W ocenie Ministra „osoba prawna jest podmiotem abstrakcyjnym, zatem ówczesny prawodawca uznał, że nie można przekazać nieruchomości, wprowadzić w posiadanie nieruchomości, oddać w zarząd osobie prawnej w inny sposób niż poprzez wydanie jej konkretnym osobom fizycznym, stanowiącym organ tej osoby prawnej, a zatem w świetle art. 12 ust. $1 \mathrm{w}$ związku z art. 2 ust. 4 dekretu z dnia 8 marca 1946 r. otrzymanie w zarząd nieruchomości było skutkiem uzyskania własności danej nieruchomości z mocy prawa. Wobec powyższego brak jest podstaw do twierdzenia, że «zarząd» wykluczał prawo własności”. Minister odniósł się także do twierdzeń o charakterze prawnym pisma okólnego nr 20 Ministra Gospodarki Komunalnej z dnia 23 kwietnia 1959 r. w sprawie poniemieckich majątków kościelnych na Ziemiach Zachodnich. Minister uznał, że „pisma okólne ministrów nie stanowiły w 1959 r. źródeł prawa, nie mogły zatem zmieniać przepisów dekretu wydanego z mocą ustawy". Minister stwierdził również, że fakt wystąpienia przez organ I instancji

73 Decyzja Wojewody Dolnośląskiego z dnia 21 czerwca 2002 r., sygn. NGK. VIII.7721-104/01. 
o opinię prawną do organu II instancji należy uznać za naruszenie zasady dwuinstancyjności postępowania administracyjnego ${ }^{74}$.

Od 15 kwietnia 2003 r. trwała korespondencja pomiędzy Urzędem Wojewody Dolnośląskiego a Urzędem Miejskim Wrocławia oraz Kościołem. W tym czasie, aż do 18 czerwca 2007 r. nie została wydana żadna decyzja w sprawie, ani też nie zostało zawieszone postępowanie w sprawie zwrotu zabranej przez władze komunistyczne nieruchomości kościelnej. W wielu pismach Wojewoda Dolnośląski w sposób jednoznaczny uznał roszczenia Kościoła za uzasadnione ${ }^{75}$.

Wejście w życie znowelizowanego przepisu art. 4 ustawy spowodowało konieczność uchylenia dotychczasowej decyzji w przedmiocie zwrotu upaństwowionej nieruchomości kościelnej. Zauważyć należy, że Wojewoda po otrzymaniu decyzji organu II instancji prowadził postępowanie od marca 1999 r. do czerwca 2002 r., czyli ponad 3 lata. Przewlekłość prowadzenia postępowania rewindykacyjnego zainicjowanego w 1995 r. doprowadziła do wydania decyzji po dacie 30 maja 1998 r., tj. po zmianie brzmienia art. 4 ustawy, co w sposób znaczący zmieniło sytuację Kościoła. Wydanie decyzji przez organ I instancji lub wydanie decyzji przez organ II instancji w czasie obowiązywania pierwotnego brzmienia art. 4 ustawy spowodowałoby, że Kościół stałby się właścicielem nieruchomości objętych wnioskiem, bez konieczności dowodzenia następstwa prawnego po niemieckiej gminie baptystycznej funkcjonującej we Wroclawiu przed $1945 \mathrm{r}$.

Po wydaniu decyzji przez organ II instancji (decyzja Ministra Spraw Wewnętrznych i Administracji z dnia 5 marca 1999 r.), organ I instancji wystąpił do Gminy Wrocław w sprawie ewentualnego przekazania Kościołowi nieruchomości zamiennej. Odpowiedź została udzielona po 6 miesiącach i wnikało z niej, że na dzień 7 kwietnia 2000 r. Gmina Wrocław nie dysponowała nieruchomością, która mogłaby zostać przekazana w zamian za nieruchomości objęte wnioskiem rewindykacyjnym. Jednocześnie

74 Decyzja Ministra Spraw Wewnętrznych i Administracji z dnia 23 września 2002 r., sygn. WP.6780/23/02, s. 9.

75 Pismo Wojewody Dolnośląskiego do Prezydenta Miasta Wrocławia z dnia 15 kwietnia 2003 r.; pismo Wojewody Dolnośląskiego do Dyrektora Wydziału Mienia i Geodezji Urzędu Miejskiego Wrocławia z dnia 7 maja 2004 r. 
organ I instancji wystąpił o wykładnię przepisów ustawy do organu II instancji, a ponadto $\mathrm{w}$ drodze postanowienia zawiesił postępowanie rewindykacyjne do czasu wyodrębnienia lokali znajdujących się w przedmiotowej nieruchomości. Wspomniane postanowienie zostało uchylone wraz ze stwierdzeniem naruszenia prawa ${ }^{76}$.

Nowelizacja art. 4 ustawy skutkowała odmową przyznania prawa własności nieruchomości kościelnej. Kluczowy przy wydawaniu decyzji okazał się brak regulacji przejściowej. Przepis art. 7 pkt $6 \mathrm{w}$ związku $\mathrm{z}$ art. 14 ustawy nowelizującej, ze względu na zmienioną treść art. 4 ustawy, nie dotyczył postępowań w sprawach nieruchomości położonych na obszarach, które nie znajdowały się na terytorium Rzeczypospolitej Polskiej przed 1 września 1939 r. O tym, że wymienione przepisy nie regulują skutków zmiany art. 4 ustawy wobec postępowań prowadzonych dotąd przez wojewodów, świadczą wyraźnie także przepisy normujące działanie Komisji Regulacyjnej, które stanowią, że „tworzy się Międzykościelną Komisję Regulacyjną, zwaną dalej «Komisją», w celu ostatecznego uregulowania spraw majątkowych między Państwem a kościołami i ich osobami prawnymi, które zgłosiły roszczenia $\mathrm{w}$ trybie i na zasadach określonych w: [...] art. 40-42 ustawy z dnia 30 czerwca 1995 r. o stosunku Państwa do Kościoła Chrześcijan Baptystów w Rzeczypospolitej Polskiej"’77.

Reasumując, to nie nowelizacja art. 4 ustawy wpłynęła na konieczność wydania decyzji uchylającej i ponowne rozpatrzenie sprawy rewindykacyjnej Drugiego Zboru we Wrocławiu ${ }^{78}$, lecz przewlekłość postępowania, która spowodowała, że kolejną już decyzję trzeba było wydać z uwzględnieniem nowej treści cytowanej ustawy. Przewlekłość postępowania w sprawie zwrotu nieruchomości kościelnej należącej do Kościoła uznana została za naruszającą prawo do rozpoznania sprawy w rozsądnym terminie (art. 6 Konwencji o Ochronie Praw Człowieka i Podstawowych Wolności). Najdalej idącym skutkiem przewlekłości było pozbawienie

76 Postanowienie Ministra Spraw Wewnętrznych i Administracji z dnia 17 grudnia 2001 r., sygn. W.P. 0212/97/00.

77 Zob. art. 38a ust. 1 pkt 3 ustawy z dnia 17 maja 1989 r. o gwarancjach wolności sumienia i wyznania, tekst jedn. Dz. U. z 2017 r. poz. 1153.

78 Decyzja Ministra Spraw Wewnętrznych i Administracji z dnia 5 marca 1999 r., sygn. WP.3621/XII/84/96/EM. 
Kościoła prawa domagania się zwrotu nieruchomości znajdujących się przed 1939 r. poza Polską.

\section{POSTĘPOWANIE ADMINISTRACYJNE PO WYDANIU WYROKU TRYBUNAŁU KONSTYTUCYJNEGO W SPRAWIE SK 25/02}

Z uwagi na wątpliwości co do kwestii zgodności z Konstytucją ustawy nowelizującej, która istotnie odebrała Kościołowi prawo żądania przywrócenia prawa własności, konieczne było skierowanie sprawy do Trybunału Konstytucyjnego. Ustawodawca nie uregulował w przepisach przejściowych skutków nowelizacji ustawy dla trwających postępowań, prowadzonych w sprawie przywrócenia własności nieruchomości. Dlatego też organy i sądy administracyjne orzekające w sprawie Polskiego Kościoła Ewangelicznych Chrześcijan Baptystów we Wrocławiu zastosowały prawo obowiązujące w chwili orzekania, stosownie do wskazań wynikających z wyroku Trybunału w sprawie SK 25/02. Uwzględnienie wskazań Trybunału Konstytucyjnego oraz zastosowanie nowelizacji art. 4 ustawy nastąpiło po raz pierwszy na mocy decyzji Wojewody Dolnośląskiego $\mathrm{z}$ dnia 18 czerwca $2007 \mathrm{r}^{79} \mathrm{i}$ tym samym otworzyło ostatni etap postępowania rewindykacyjnego, zakończonego finalnie wyrokiem NSA w 2013 r., zatem po 17 latach od złożenia wniosku rewindykacyjnego.

Konsekwencją wydania wyroku Trybunału Konstytucyjnego w sprawie SK 25/02 była konieczność uwzględnienia nowej treści art. 4 ustawy oraz wskazań zawartych w tym wyroku odnoszących się do następstwa prawnego zborów, organizacji i gmin baptystycznych działających na terytorium Rzeczypospolitej przed dniem 1 września 1939 r. Ponadto z treści wyroku wynikała konieczność uwzględnienia uchwały Sądu Najwyższego z dnia 19 grudnia 1959 r. dotyczącej interpretacji art. 2 ust. 4 dekretu z dnia 8 marca 1946 r. o majątkach opuszczonych i poniemieckich.

W uzasadnieniu decyzji Wojewody Dolnośląskiego z dnia 18 czerwca 2007 r. stan faktyczny został rozszerzony o nowe okoliczności, które w dotychczasowym postępowaniu trwającym od 15 listopada 1995 r. nie

79 Decyzja Wojewody Dolnośląskiego z dnia 18 czerwca 2007 r., sygn. SP.4.RR. II.7721-104/01. 
zostały dostatecznie wyjaśnione. Organ ustalił, że nieruchomość położona we Wrocławiu przy ul. Łukasińskiego 20 (dawna niemiecka nazwa ul. Marthastrasse) do 1945 r. stanowiła własność jednostki organizacyjnej Kościoła Chrześcijan Baptystów działającego na terytorium Rzeszy Niemieckiej. Decyzją z dnia 4 września 1946 r. Wojewoda Wrocławski, powołując się na przepis art. 2 ust. 4 dekretu z dnia 8 marca 1946 r. o majątkach opuszczonych i poniemieckich, oddał w zarząd kościół po niemieckich baptystach przy ul. Marty 20, wraz z posesją przynależną do tego kościoła. Przedmiotowa nieruchomość została oznaczona geodezyjnie jako parcela nr 1077/42 o pow. $785 \mathrm{~m}^{2}$, a miejscowo właściwy sąd (Sąd Powiatowy we Wrocławiu) w 1956 r. założył dla niej księgę wieczystą nr 945. W dziale II tej księgi jako właściciel nieruchomości do chwili obecnej figuruje parafia Polskiego Kościoła Ewangelicznych Chrześcijan Baptystów we Wrocławiu, a jako podstawa nabycia wpisane zostały: decyzja Wojewody Wrocławskiego z dnia 4 września 1946 r., zaświadczenie Prezydium Miejskiej Rady Narodowej we Wrocławiu z dnia 3 grudnia 1955 r. W treści tego zaświadczenia stwierdzono, że ,nieruchomość położona we Wrocławiu przy ul. Łukasińskiego 20, oznaczona jako parcela 1077/42 o pow. $785 \mathrm{~m}^{2}$ nie była administrowana przez prezydium i na podstawie dekretu $\mathrm{z}$ dnia 8 marca 1946 r. o majątkach opuszczonych i poniemieckich przeszła na własność Parafii Polskiego Kościoła Ewangelicznych Chrześcijan Baptystów we Wrocławiu" "80.

Minister jednoznacznie stwierdził, że materialną podstawę prawną wniosku o zwrot prawa własności stanowi art. 40 ustawy, ale po spełnieniu przesłanki z art. 39 ust. 1 pkt 1. Przesłanka ta zaś wymaga uprzedniego władania nieruchomością przez podmioty wymienione w art. 4 ustawy, czyli zbory, organizacje i gminy baptystyczne działające przed dniem 1 września 1939 r. na terytorium Rzeczypospolitej Polskiej w jego ówczesnych granicach. Z tego powodu przywrócenie Kościołowi prawa własności przedmiotowych nieruchomości nie jest prawnie dopuszczalne, gdyż Wrocław znajdował się poza obszarem Rzeczypospolitej Polskiej 1 września 1939 r. Jednocześnie Minister dokonał analizy konsekwencji wpisów prawa własności w księgach wieczystych. Na dzień wydawania decyzji przez Ministra, w obrocie prawnym funkcjonowały jednocześnie trzy

80 APW, Urząd Wojewódzki Wrocławski sygn. VI/688, s. 19. 
różne księgi wieczyste, a mianowicie: księga wieczysta 945 prowadzona dla działki nr 1077/42, księga wieczysta nr 35905 prowadzona dla działki nr 32 (budynek Zboru), a także księga wieczysta nr 63650 prowadzona dla działki nr 39 (budynek mieszkalny). Treści tych ksiąg nie daje się ze sobą pogodzić. Każda z tych ksiąg korzysta $\mathrm{z}$ ustawowego domniemania zgodności wpisu z rzeczywistym stanem prawnym. Usunięcie niezgodności między stanem prawnym nieruchomości ujawnionym w księdze wieczystej a rzeczywistym stanem prawnym nastąpić może wyłącznie w postępowaniu przed sądem powszechnym, a nie w drodze decyzji administracyjnej wydanej w postępowaniu rewindykacyjnym ${ }^{81}$.

Minister Spraw Wewnętrznych i Administracji wydał decyzję w dniu 6 lutego 2008 r. utrzymującą w mocy zaskarżoną decyzję z dnia 18 czerwca 2007 r. W uzasadnieniu Minister podtrzymał dotychczasowe stanowisko Wojewody oraz dodał nowy wątek dotyczący następstwa prawnego kościelnych osób prawnych na Ziemiach Zachodnich i Północnych. Minister podkreślił, że niedopuszczalne jest uznanie następstwa prawnego kościelnych osób prawnych, gdyż uchwała składu siedmiu sędziów Sądu Najwyższego z dnia 19 grudnia 1959 r. określiła, że ,jednostki organizacyjne związków wyznaniowych działających w Polsce nie mogą być uważane za następców prawnych niemieckich i gdańskich osób prawnych prawa publicznego". Dodatkowo Minister stwierdził, że na terenie Rzeszy niemieckiej kościoły i związki wyznaniowe mogły działać tylko jako osoby prawa niemieckiego, a ich mienie przeszło po wojnie na własność Skarbu Państwa zgodnie $\mathrm{z}$ art. 2 ust. 1 lit. c dekretu z dnia 8 marca 1946 r. o majątkach opuszczonych i poniemieckich. Od tej decyzji Kościół złożył skargę do Wojewódzkiego Sądu Administracyjnego w Warszawie wskazując m.in. naruszenie art. 7, 8, 9, 12 k.p.a. w związku z art. $35 \S 3$ k.p.a., a także art. 2 i art. 7 Konstytucji RP poprzez zastosowanie błędnej wykładni przepisu art. 2 ust. 4 dekretu, przyjmującej, że tylko osoby prawa publicznego mogły z mocy prawa nabyć własność nieruchomości poniemieckich, a związki wyznaniowe nie są osobami prawa publicznego ${ }^{82}$.

81 Decyzja Wojewody Dolnośląskiego z dnia 18 czerwca 2007 r., sygn. SP.4.RR. II.7721-104/01.

82 Decyzja Ministra Spraw Wewnętrznych i Administracji z dnia 6 lutego 2008 r., sygn. DWRMNiE-6780-35/07/JB. 
Wojewódzki Sąd Administracyjny w Warszawie w dniu 12 września 2008 r. wydał wyrok w przedmiocie odmowy przywrócenia prawa własności nieruchomości poprzez oddalenie skargi na decyzję z dnia 6 lutego $2008 \mathrm{r}$. W ocenie sądu zarzut naruszenia przez organ art. 2 ust. 4 dekretu z dnia 8 marca 1946 r. o majątkach opuszczonych i poniemieckich był chybiony z uwagi na to, że przedmiotem postępowania była sprawa dotycząca restytucji mienia kościelnego w oparciu o przepisy ustawy z dnia 30 czerwca 1995 r., a nie sprawa nabycia tego mienia w trybie wspomnianego dekretu. Przywołanie przez organy w dotychczasowych rozstrzygnięciach dekretu z dnia 8 marca 1946 r. oraz wykładni przepisów dokonanej przez Sąd Najwyższy w uchwale z dnia 19 grudnia 1959 r. nie miały znaczenia dla rozstrzygnięcia niniejszej sprawy. Sąd w uzasadnieniu odniósł się do zarzutów opieszałości organów przy rozpoznawaniu sprawy stwierdzając, że choć doszło do przewlekłości, to nie miała ona wpływu na merytoryczną wartość podjętych w toku wszystkich spraw rozstrzygnięc ${ }^{83}$.

Od niniejszego wyroku Kościół złożył skargę kasacyjną do Naczelnego Sądu Administracyjnego, która została oparta na naruszeniu prawa materialnego, tj. art. 40 ust. $1 \mathrm{w}$ związku z art. 39 ust. 1 oraz z art. 4 ustawy poprzez niewłaściwą wykładnię; naruszeniu art. 2 ust. 4 dekretu z dnia 8 marca 1946 r. o majątkach opuszczonych i poniemieckich poprzez niezastosowanie tego przepisu w sprawie. Naczelny Sąd Administracyjny wydał wyrok w dniu 13 października 2009 r. oddalający skargę kasacyjną. W uzasadnieniu wyroku sąd wskazał, że zarzut naruszenia art. 40 ust. $1 \mathrm{w}$ związku z art. 39 ust. 1 oraz w związku z art. 4 art. 1 ustawy nie jest trafny. Poza sporem jest, że nieruchomość, której przywrócenia własności domaga się Kościół, przed dniem 1 września 1939 r. znajdowała się poza ówczesnymi granicami państwa polskiego, zatem Kościół Chrześcijan Baptystów i jego osoby prawne w świetle art. 4 nie są następcami prawnymi i nie mogą domagać się przywrócenia im własności przedmiotowej nieruchomości w trybie art. 40 ust. 1 tej ustawy. $Z$ kolei

${ }^{83}$ Wyrok Wojewódzkiego Sądu Administracyjnego w Warszawie z dnia 12 września 2008 r., sygn. akt I SA/Wa 568/08. 
zarzut naruszenia art. 2 ust. 4 dekretu był bezzasadny, gdyż nie znajdował zastosowania w niniejszej sprawie ${ }^{84}$.

Istotą postępowania rewindykacyjnego było przywrócenie prawa własności, a nie stwierdzanie bezczynności organów, jaka miała miejsce w toku całego postępowania. Dopiero odmowa przywrócenia prawa własności nieruchomości, na mocy prawomocnego wyroku Naczelnego Sądu Administracyjnego z dnia 13 października 2009 r., pozwoliła na złożenie skargi do Europejskiego Trybunału Praw Człowieka w oparciu o zarzut naruszenia art. 6 Konwencji o Ochronie Praw Człowieka i Podstawowych Wolności wskutek przewlekłości postępowania rewindykacyjnego.

\section{WNIOSKI KOŃCOWE}

Pomysł zjednoczenia kilku ugrupowań ewangeliczno-baptystycznych był krokiem naprzód do zwiększenia szans na odzyskanie zabranych przez władze państwowe po II wojnie światowej nieruchomości kościelnych. Powstanie Polskiego Kościoła Ewangelicznych Chrześcijan Baptystów dawało nadzieję na szybkie odzyskanie utraconych nieruchomości na terenie całej Polski. Nieruchomość należąca do Parafii Polskiego Kościoła Ewangelicznych Chrześcijan Baptystów we Wrocławiu została pozostawiona na własność baptystom. W wyniku przyjętej przez Sąd Najwyższy w drodze uchwały z dnia 19 grudnia 1959 r. interpretacji art. 2 ust. 4 dekretu z dnia 8 marca 1946 r. o majątkach opuszczonych i poniemieckich wspomniany majątek stał się własnością Skarbu Państwa. Drugi Zbór we Wrocławiu na podstawie przepisów ustawy indywidualnej wszczął starania o uzyskanie prawa do nieruchomości. W trakcie trwania procedury administracyjnej w przedmiocie przywrócenia prawa własności doszło do zmiany kręgu podmiotów uprawnionych, co było związane z nowelizacją art. 4 ustawy indywidualnej. Zmiana treści tego przepisu pozbawiła Kościół prawa do zwrotu nieruchomości kościelnych położonych poza granicami państwa polskiego sprzed II wojny światowej. Trybunał Konstytucyjny w wyroku z dnia 8 listopada 2005 r. (sygn. akt SK 25/02) po-

84 Wyrok Naczelnego Sądu Administracyjnego z dnia 13 października 2009 r., sygn. akt II OSK 33/09. 
twierdził, że ograniczenie następstwa prawnego zborów, organizacji i gmin baptystycznych jedynie do granic terytorium Rzeczypospolitej Polskiej z dnia 1 września 1939 r. jest zgodne z Konstytucją RP i wyrównuje prawa pozostałych związków wyznaniowych w Polsce w przedmiotowej kwestii. Zatem wydanie wyroku przez Trybunał Konstytucyjny w 2005 r. otworzyło ostatni etap postępowania rewindykacyjnego. Trwające ponad 13 lat postępowanie rewindykacyjne stanowiło rażące naruszenie prawa Kościoła do rozpoznania sprawy $\mathrm{w}$ rozsądnym terminie, co zostało potwierdzone przez Trybunał w Strasburgu w wyroku z dnia 5 kwietnia 2018 r. Stan faktyczny niniejszej sprawy pozwala na stwierdzenie, że zwrot prawa własności nieruchomości należącej do Drugiego Zboru Kościoła Chrześcijan Baptystów we Wrocławiu może nastąpić w innym trybie niż administracyjny.

\section{BIBLIOGRAFIA}

Borecki, Paweł. 2007. „Zasada równouprawnienia wyznań w prawie polskim”. Studia z Prawa Wyznaniowego 10: 115-159.

Brzechczyn, Krzysztof. 2010. „Zabiegi o odzyskanie prawa do użytkowania budynków kościelnych w Poznaniu i w Kaliszu. Przyczynek do relacji władze PRL a Polski Kościół Chrześcijan Baptystów”. W: Władze Polski Ludowej a mniejszościowe zwiazki wyznaniowe, red. Tadeusz J. Zieliński, s. 159-181. Warszawa-Katowice: Wydawnictwo Credo.

Czajko, Edward. 2000. Sytuacja prawna ruchu zielonoświątkowego w Polsce w perspektywie historycznej. Warszawa: Instytut im. T. B. Barratta.

Czajko, Edward. 2012. „Zielonoświątkowcy w Nowogródzkiem w latach 1919-1945”. Rocznik Teologiczny 54/1-2: 229-244.

Dziobek-Romański, Jacek. 2001. „Zasady uznawania związków religijnych w prawie polskim w latach 1944-1989". Roczniki Nauk Prawnych 11: 69-109.

Dziobek-Romański, Jacek. 2004. Uznawanie związów religijnych $w$ Polsce (1944-1989) narzędziem dyskryminacyjnej polityki władz. Lublin: Wydawnictwo KUL.

Kamiński, Michał. 2012. Kościół Zielonoświatkowy w Polsce w latach 1988-2008, Warszawa: Wydawnictwo Arka.

Krawczyk, Michał. 2014. „Urząd do Spraw Wyznań a kwestia własności kościelnych majątków poniemieckich na Ziemiach Zachodnich i Północnych". 
Zeszyty Naukowe UPH w Siedlcach, seria: Administracja i Zarzadzanie 100: 119-130.

Krzysztofek, Katarzyna. 2018. Położenie prawne $i$ działalność nierzymskokatolickich kościołów $i$ związów wyznaniowych $w$ Krakowie $w$ latach 1945-1970. Kraków: Wydawnictwo Uniwersytetu Jagiellońskiego.

Mazurkiewicz, Dariusz. 2006. „Zagadnienie własności kościelnych majątków poniemieckich na Ziemiach Zachodnich i Północnych w latach 1945-1973”. Studia Paradyskie 16: 221-240.

Pielka, Mateusz. 2018. „Chrześcijańskie mniejszości wyznaniowe w Toruniu w latach 1920-1939". Perspectiva 2: 135-148.

Schultz, Ludwig. 1912. Das preußische Feuerbestattungsrecht. Gesetz vom 14. September 1911 nebst Erläuterungen sowie Erörterung der übrigen in Betracht kommenden Gesetze und Verordnungen, Berlin: Springer.

Sztyk, Romuald. 1991. „Kościoły i związki wyznaniowe jako podmioty praw majątkowych". Rejent 1: 63-99.

Tomaszewski, Henryk. 1991. Wyznania typu ewangeliczno-baptystycznego wchodzace w skład Zjednoczonego Kościoła Ewangelicznego w latach 1945-1956. Tomaszów Mazowiecki: Słowo i Życie.

Tomaszewski, Henryk. 2009. Zjednoczony Kościót Ewangeliczny (1947-1987). Warszawa: Kompas.

Walencik, Dariusz. 2007. „Zmiany w ustawie o stosunku państwa do Polskiego Autokefalicznego Kościoła Prawosławnego dotyczące regulacji spraw majątkowych". W: Prawo i Religia, t. I, red. Tadeusz J. Zieliński, s. 67-85. Warszawa: Wydawnictwo ChAT.

Walencik, Dariusz. 2010. „Regulacja stanu prawnego nieruchomości związków wyznaniowych na Ziemiach Zachodnich i Północnych jako praktyczna realizacja zasady wolności religijnej”. W: Idea wolności w ujęciu historycznym i prawnym. Wybrane zagadnienia, red. Ewa Kozerska, Piotr Sadowski, Andrzej Szymański, s. 165-187. Toruń: Wydawnictwo Adam Marszałek.

Winiarczyk-Kossakowska, Małgorzata. 2004. Ustawy III Rzeczypospolitej o stosunku państwa do kościołów chrześcijańskich. Warszawa: Elipsa.

Zamirski, Konrad. 2020. „Rewindykacja mienia Kościoła Chrześcijan Baptystów w RP przed Międzykościelną Komisją Regulacyjną - aspekty prawne”. W: Człowiek, Państwo, Kościót. Księga Jubileuszowa dedykowana księdzu profesorowi Arturowi Mezglewskiemu, red. Paweł Sobczyk, Piotr Steczkowski, s. 739-753. Lublin: Wydawnictwo Academicon.

Zieliński, Tadeusz. 2010. „Rewindykacja nieruchomości Kościoła Ewangelicko-Augsburskiego na terenie Gdańska po 1989 r. (postępowania przed Komisją Regulacyjną)”. Studia z Prawa Wyznaniowego 13: 5-24. 


\section{THE PROBLEM OF THE RESTITUTION OF CHURCH PROPERTY OF THE POLISH EVANGELICAL CHRISTIAN BAPTIST CHURCH IN WROCLAW}

Abstract

The main aim of the paper is to present the course of the restitution proceedings concerning the church property of the parish of the Polish Evangelical Christian Baptist Church in Wrocław, as well as to analyse the administrative decisions issued during the proceedings. Special attention is given to the legal issues related to applying art. 2 para. 4 of the decree of 8 March 1946 on abandoned and post-German properties and to the consequences of the resolution of the Supreme Court of 19 December 1959 for the legal effects in the interpretation of art. 2 para. 4 of the decree. A definitive decision on this issue that refused to grant the right of ownership to the Church was issued only 13 years after the restitution application had been submitted. The excessive duration of the proceedings was confirmed by the judgment of the European Court of Human Rights (Application no. 32045/10). The Second Congregation in Wrocław (the legal successor of the above-mentioned parish) did not recover the property lost after World War II under the provisions of the act regulating the legal situation of the Church of Christian Baptists in the Republic of Poland. A close examination of the circumstances of the lengthy restitution litigation indicates that in order to resolve the question of the right of ownership of this property, it is necessary to pursue another route than the administrative one.

Key words: restitution; church property; Polish Evangelical Christian Baptist Church; post-German property; Baptists 
